\title{
Os limites do diálogo intercultural em contextos de guerra interétnica e pluralismo jurídico: o caso dos Waorani e Tagaeri-Taromenane no Equador The limits of intercultural dialogue in contexts of interethnic warfare and legal pluralism: the case of the Waorani and Tagaeri-Taromenane in Ecuador
}

\author{
Felipe Nascimento Araujo (1) | Diego Andrés Parrall (1) \\ Universidade Federal do Pará. Belém, Pará, Brasil \\ "Universidad de Cuenca. Cuenca, Equador
}

\begin{abstract}
Resumo: Neste artigo, propomos um debate atual sobre o pensamento decolonial e a 'tradução intercultural' dos direitos humanos, dentro de um marco de reconhecimento dos direitos, do pluralismo jurídico e do neocolonialismo global. O objetivo é descrever os limites do diálogo intercultural em um contexto de judicialização de guerra interétnica tradicional entre povos indígenas de recente contato e em situações de isolamento voluntário na Amazônia equatoriana, território atravessado e exacerbado por atividades econômicas de mercado, promovidas por agentes e atores públicos e privados, nacionais e transnacionais. $\mathrm{O}$ artigo identifica padrões de poder que revelam a tensão entre o universalismo abstrato dos direitos humanos e as instituiçôes da organização social tradicional dos povos indígenas Waorani e dos Tagaeri-Taromenane. A descrição das tensões e dos limites nos permite relativizar os diferentes significados do diálogo intercultural através do perspectivismo ameríndio e do pensamento decolonial.
\end{abstract}

Palavras-chave: Interculturalidade. Diálogo intercultural. Pensamento decolonial. Pluralismo jurídico. Direitos humanos. Genocídio.

\begin{abstract}
We propose a current debate on decolonial thinking and the 'intercultural translation' of human rights, within a framework of recognition of rights, legal pluralism and global neocolonialism. The goal is to describe the limits of intercultural dialogue in a context of judicialization of traditional interethnic war between indigenous peoples of recent contact and in situations of voluntary isolation in the Ecuadorian Amazon, territory crossed and exacerbated by economic activities, promoted by public agents and private, national and transnational actors. The article identifies patterns of power that reveal the tension between the abstract universalism of human rights and the institutions of the traditional social organization of the Waorani and Tagaeri-Taromenane indigenous peoples. The description of tensions and limits allows us to relativize the different meanings of intercultural dialogue through Amerindian perspectivism and decolonial thinking.
\end{abstract}

Keywords: Interculturality. Intercultural dialog. Decolonial thought. Legal pluralism. Human rights. Genocide.

Araujo, F. N., \& Parra, D. A. (2020). Os limites do diálogo intercultural em contextos de guerra interétnica e pluralismo jurídico: o caso dos Waorani e Tagaeri-Taromenane no Equador. Boletim do Museu Paraense Emílio Goeldi. Ciências Humanas, 15(3), e20190154. doi: 10.1590/2178-2547-BGOELDI-2019-0154

Autor para correspondência: Felipe Nascimento Araujo. Universidade Federal do Pará. Programa de Pós-Graduação em Sociologia e Antropologia. Rua Augusto Corrêa, 01 - Guamá. Belém, PA, Brasil. CEP 66075-110 (feliperioaraujo@gmail.com).

Recebido em 10/02/2020

Aprovado em 12/06/2020

Responsabilidade editorial: Jorge Eremites de Oliveira 


\section{INTRODUÇÃO}

Este artigo tem como eixo central a questão do direito à guerra e do direito à vida em contexto de pluralismo jurídico. Partindo da guerra interétnica realizada entre os Waorani e os Tagaeri-Taromenane, tentaremos elucidar alguns problemas relacionados a uma particularidade alarmante desta guerra: sendo os Tagaeri-Taromenane um povo indígena pequeno e em isolamento voluntário, os massacres perpetrados pelos Waorani põem em risco a própria sobrevivência deste povo. Neste sentido, tensionaremos as noções de pluralismo jurídico e interculturalidade com uma premissa assumida desde já por nós: o Estado tem responsabilidade de prevenir o genocídio e o etnocídio ${ }^{1}$ de povos indígenas, entendendo-se por genocídio o extermínio do povo enquanto sua morte física e etnocídio, a morte da sua identidade cultural. Se a guerra tradicional interétnica põe em risco a sobrevivência de um povo, o que fazer com o pluralismo jurídico e a interculturalidade? Se nas situações de extermínio nas quais os agentes genocidas e etnocidas não são indígenas, há bases jurídicas sólidas para seu enquadramento enquanto crime; quando a questão do direito 'coletivo' de povos indígenas de praticar a sua cultura se opõe ao direito à vida (que é tanto 'humano' - individual - quanto 'coletivo'), a situação se complica para a prática jurídica intercultural (o pluralismo jurídico).

Ao mesmo tempo em que os massacres perpetrados pelos Waorani no contexto da guerra interétnica fogem à noção de genocídio, sua consequência potencial é um genocídio. A investigação envolve o conceito de direitos humanos que se alicerça em um bem conhecido conjunto de pressupostos tipicamente anglo-europeuocidentais (Santos, 2001, p. 16). A retórica emancipadora deste conceito foi incorporando as demandas de reconhecimento político, jurídico e cultural dos povos indígenas em uma categoria de 'direitos coletivos' nos tratados e instrumentos internacionais de direitos humanos, como a Convenção 169, da Organização Internacional do Trabalho (OIT), ou a Declaração Universal dos Direitos dos Povos Indígenas, da Organização das Nações Unidas (ONU), de 2007. Posteriormente, estes foram cristalizados nas Constituições latino-americanas como reconhecimento da característica plurinacional e multiétnica das sociedades, o que teve como consequência a consolidação do 'pluralismo jurídico' e a preservação do direito coletivo indígena à autodeterminação e à sobrevivência social e cultural; no entanto, a tensão entre reconhecimento dos direitos coletivos e direitos humanos não deixou de ser intensa. As Constituições do Equador e da Bolívia reconheceram também a interculturalidade como uma categoria alternativa à solução de conflitos em que o multiculturalismo dos direitos humanos foi incapaz de restringir o colonialismo de poder, e se circunscreveu em seus textos constitucionais como uma proposta para o diálogo e a boa convivência entre culturas.

Sem deixar de levar em conta a importância das iniciativas dentro do campo político-jurídico-legislativo com a incorporação da 'interculturalidade', é necessário considerar de maneira crítica seus alcances e seus limites reais, para que exista sua contínua construção reflexiva. O presente artigo busca estudar os limites do 'diálogo intercultural', quando se trata de conflitos entre povos indígenas em situação de isolamento voluntário e recente contato e o Estado, em contexto de guerra interétnica, para observar como a 'colonialidade' se estende aos direitos humanos e os tensiona com dispositivos de dupla subalternização. Na prática, e no caso relevante que apresentaremos neste estudo, a interculturalidade, em sua ideia mais abstrata, não logra ultrapassar a barreira das diferenças, e sua realização é mais uma idealização

O etnocídio é considerado um crime na Constituição do Equador, no Artigo 57, inciso 2: "Los territorios de los pueblos en aislamiento voluntario son de posesión ancestral irreductible e intangible, y en ellos está vedada todo tipo de actividad extractiva. El Estado adoptará medidas para garantizar sus vidas, hacer respetar su autodeterminación y voluntad de permanecer en aislamiento, y precautelar la observancia de sus derechos. La violación de estos derechos constituirá delito de etnocidio, que será tipificado por la ley" (Equador, 2008).

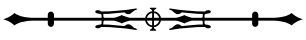


do que um fato. $\bigcirc$ que se pode ver no Equador, em particular, e na América indígena, em geral, é a proposta de um diálogo intercultural sendo feita pelos povos indígenas, mas também sendo apropriada e imposta pelos Estados para balizar uma retórica em políticas que querem aparentar igualdade, mas que costumam simplesmente utilizar esta designação (intercultural) em políticas de usurpação dos territórios, bem como das capacidades de autodeterminação coletiva.

Este é o caso dos massacres do povo em isolamento voluntário Tagaeri-Taromenane, na Amazônia do Equador, ocorrido em março de 2013, judicializado por operadores jurídicos do Estado equatoriano. $\bigcirc$ caso tem um alcance amplo e paradigmático, pois nos encontramos diante de uma situação de relações interculturais de interlegalidade, onde o aparato ético-moral ocidental - os direitos humanos - e as tradições indígenas em jogo precisam de uma tradução propriamente intercultural, e onde a tensão torna evidentes as contradições que confrontam o modelo de conhecimento e os valores ocidentais com pretensões de universalidade (com o conceito de pessoa e indivíduo como sujeitos centrais do direito) e as perspectivas e formas de organização social indígena.

A guerra baseada na vingança é persistente e comum na Amazônia indígena e tem sido relatada por cronistas e antropólogos, tanto no Brasil, com os Tupinambá (Metraux, 1950; Fernandes, 2006 [1970]; Carneiro da Cunha \& Viveiros de Castro, 2017 [1985]; Viveiros de Castro, 2017), os Yanomami (Kopenawa \& Albert, 2010) e os Nambiquara, no Mato Grosso (Lévi-Strauss, 1976 [1942]; Price, 1983), quanto na Amazônia do Equador, com os Shuar e Achuar (Descola, 1993; Colajanni, 1984), e os Waorani e TagaeriTaromenani (Cabodevilla, 2003, 2016; Narváez, 2016). No entanto, a vingança não é exclusiva das sociedades amazônicas, nem reservada ao passado próximo ou remoto, foi prática comum dos Nivaclé-Chulupi, Toba e Pilagá, no Pilcomayo médio (Clastres, 1987 [1981]; Bossert \& Siffredi, 2011), dos Mataco-Weenhayek e MatacoWichi, do Gran Chaco de Bolívia, Paraguai e Argentina
(Alvarsson, 1999, 2010; Califano, 1999; Dasso, 2007), também dos Paipai e Kaliwa, da Baja Califórnia (Mixco, 1984), dos Nuer, na região alta do rio Nilo, em África (Evans-Pritchard, 1977 [1940]), e dos Azande, de África do Sul (Gluckman, 2009 [1955]). É uma prática ainda em vigor na sociedade contemporânea albanesa (Resta, 2002) ou no código de vingança 'barbaricina' como um sistema de solução tradicional de controvérsias dos pastores da Barbagia, da Sardenha (Pigliaru, 1959; Sassu, 2007; Scionti, 2008; Romero, 2018). Em geral, as ciências humanas, como direito, sociologia ou história, carregam um preconceito evolucionista, essencialista, etnocêntrico em torno da vingança. $\bigcirc$ imaginário contemporâneo a apresenta como justiça privada, primitiva, fora do direito e da justiça, pré-jurídica, marcando, assim, uma distância entre direito e vingança, entre vingança e punição. Este preconceito não é estranho aos operadores jurídicos do Estado, que realizam o exercício da justiça intercultural.

A metodologia deste artigo consiste em realizar uma etnografia jurídica de um caso específico para, então, realizar uma discussão sobre a interculturalidade enquanto proposta para a construção de um pluralismo jurídico. Na etnografia jurídica, descrevemos e analisamos comportamentos concretos dos operadores do Estado para resolver um conflito intercultural complexo (Castro, 2014), que inclui o estudo etnográfico do expediente judicial como dispositivo burocrático através do qual é possível olhar e fazer público seu funcionamento (Muzzopappa, 2010; Barrera, 2009). Para isso, nos debruçamos sobre material documental, mapas, notas de imprensa, leis, relatórios e perícias antropológicas, etnografias documentais, imagens, testemunhos, relatos e narrativas sobre a guerra entre os povos em isolamento voluntário e de recente contato na Amazônia do Equador e sobre aquilo que se configura como campo da justiça, conflito e diálogo intercultural. O caráter interdisciplinar deste artigo visa articular metodologias que combinam um trabalho de campo de etnografia em burocracias judiciais (Juárez Ortiz, 2018), com acesso físico e digital ao arquivo oficial do Estado, 
para olhar as interações dos sujeitos que vão aos tribunais, com análise situacional e pesquisa bibliográfica no campo da etnologia amazônica indígena. Trata-se de fazer uma leitura antropológica do expediente judicial que permita dar conta de práticas, processos e relações da sociedade nacional e do Estado com os povos indígenas.

Os problemas relacionados ao diálogo intercultural que são abordados aqui dizem respeito às condições de produção de um pluralismo jurídico. Não teremos espaço, neste momento, para aprofundar a descrição das epistemologias Waorani que embasam sua atividade guerreira e de vingança. Quanto ao tratamento dado por nós às ações dos Tagaeri-Taromenane, cabe ressaltar a particularidade deste paradoxo que é uma etnografia com povos em isolamento voluntário. Não é irrefletido aqui o uso do etnônimo Tagaeri-Taromenane: entendemos que não temos como saber se estes coletivos aos quais designamos por este etnônimo também se identificam por ele. Sabemos apenas que é por este etnônimo que os Waorani os chamam. Da mesma forma, não procuramos aqui explicar as razões de nenhuma das ações (ataques) dos Tagaeri-Taromenane, pois, evidentemente, compreender o contexto (motivações, expectativas, percepções etc.) no qual estas ações são praticadas só seria possível a partir de um diálogo. A única observação que fazemos sobre a escolha da prática de uma política de não contato por parte dos Tagaeri-Taromenane é que ela não é exclusiva deles, e que suas motivações são insondáveis enquanto esta política perdure: o isolamento voluntário é uma resposta a determinadas situações (Gow, 2011, p. 36), que podem ser especuladas com base em contextos históricos.

Peter Gow, em seu trabalho sobre o isolamento voluntário dos Mashco, traz importantes elementos para uma reflexão e uma prática de pesquisa neste campo. $\bigcirc$ autor cita diferentes tipos de esforços para compreender a história, a língua e a cultura de um povo em isolamento voluntário: recurso a documentos históricos (por exemplo, a literatura produzida pelas ordens missionárias), leitura das etnografias, desde as mais antigas até as mais recentes, em uma perspectiva comparada. Daí a realização de especulações e inferências, que só teriam a chance de deixar de serem hipóteses no momento em que os povos deixassem o isolamento voluntário e se dispusessem a um diálogo (Gow, 2011, p. 24). Em nosso estudo de caso, nos interessa também uma investigação sobre a visão que os Waorani e outros indígenas constroem deste povo em isolamento voluntário, pois ela é trazida para o diálogo intercultural e, consequentemente, implica a formação de uma epistemologia que possa dar alicerce a um pluralismo jurídico. Pensamos, assim, que os Tagaeri-Taromenane estão para os Waorani da mesma maneira que os Mashco estão para os Piro: em determinados momentos, sua existência é mobilizada para a sua própria constituição e definição enquanto indígenas civilizados em oposição a indígenas selvagens (Gow, 2011, p. 27).

Dividiremos nossa exposição em três partes. $\mathrm{Na}$ primeira, apresentaremos o caso paradigmático de guerra entre o povo de recente contato Waorani e o povo em isolamento voluntário Tagaeri-Taromenane, o massacre e a judicialização por parte de operadores jurídicos do Estado equatoriano em seu contexto histórico e cronológico; na segunda parte, trabalharemos a relação entre guerra interétnica e a categoria de interculturalidade; e na terceira parte, estabeleceremos uma discussão relativizando as concepções de interculturalidade e diálogo intercultural, problematizando desde o perspectivismo ameríndio como formas de superar o multiculturalismo liberal. A importância e utilidade acadêmica deste trabalho é descritiva e exploratória, contribuindo para este debate, o qual está sempre aberto a uma metodologia de diálogo interdisciplinar entre a antropologia e o direito.

\section{OS WAORANI E OS TAGAERI-TAROMENANI: GUERRA, MASSACRE E JULGAMENTO}

O documentário de David Beriain (2014) mostra parte desta tragédia ocorrida em 5 de março de 2013: Ompure Omeway e sua esposa Buganey, dois indígenas do povo Waorani, aparecem atravessados por lanças de um grupo 
de Taromenane, perto da comunidade de Yarentaro, na Amazônia do Equador. Dias depois, os familiares das vítimas Waorani foram à cidade mais próxima para adquirir armas e munições para exercer o dever da vingança. Operários da Repsol, pesquisadores, ativistas e membros de organizações não governamentais (ONG) advertiram uma previsível vingança; a paróquia de Orellana advertiu a funcionários do Estado, incluindo um juiz, sobre a organização de uma expedição por parte dos Waorani para se vingarem dos Taromenane (Cabodevilla \& Aguirre, 2014).

Transcorridos dezenove dias da morte de Ompure e Buganey, em 24 de março de 2013, uma expedição com dezessete guerreiros Waorani bem equipada com armas, munições, lanças, lanternas, utensílios, comida e uma câmera fotográfica saiu da comunidade de Yarentaro, em busca dos Taromenane. Encontraram-nos em 30 de março. Existem 74 fotografias que detalham as cenas mais relevantes da tragédia (Cabodevilla \& Aguirre, 2014, pp. 87-92), porém não está claro quantos indígenas morreram. Dos relatos dos Waorani, sabemos que foram mais crianças do que adultos, mais mulheres do que homens. $\bigcirc$ ataque foi classificado como brutal e covarde, sem oportunidade de defesa. Para os autores do massacre, foi um ato de guerra interétnica, conforme sua ordem social, costumes e forma de vida. Quem são os protagonistas desta tragédia? Quem são os Waorani e os Tagaeri-Taromenane? Quais os antecedentes desta guerra interétnica judicializada pelo Estado equatoriano que tensiona o universalismo abstrato dos direitos humanos e as culturas indígenas?

Os Waorani (Huaorani ou Waos)² são uma destas nacionalidades que vêm ocupando e reivindicando para si a posse ancestral de um amplo território compartilhado durante gerações com outros grupos étnicos da Amazônia do Equador, entre os rios Napo e Curaray, nas províncias de Orellana e Pastaza, até a fronteira com o Peru. Os Waorani sofreram e resistiram a um contato forçado, prolongado e violento durante os séculos XIX e XX (Rivas Toledo, 2017, p. 49). $\bigcirc$ contato se deu inicialmente com frentes caucheira e madeireira e, posteriormente, com a frente de exploração do petróleo. "El estado delegó la función civilizatória y la obra de pacificación y contacto a misiones religiosas" (Salazar, 2017, p. 3). $\bigcirc$ antropólogo James A. Yost (1981) assinala que, em sua etapa de contato iniciado pelo Instituto Linguístico de Verão (ILV) com as famílias Waorani, durante a década de 1950, se identificaram quatro grupos parentais: a) güepeiri, b) piyemoiri, c) guequetairi ou guikitairi e d) babeiri, com população estimada, na época, em 500 indivíduos, espalhados em um amplo território de aproximadamente 20.000 km² (Trujillo, 2018, p. 275). Segundo Cipoletti (2002, p. 112):

La existencia de un frente de colonización o, más bien, la comprensión de la magnitud numérica y tecnológica fue, en mi opinión, un motivo decisivo para que los Waorani aceptaran la pacificación y consecuente reducción y redistribución en el Protectorado Territorial del ILV en Tihueno provincia de Pastaza ${ }^{3}$.

O território ancestral Waorani constitui um espectro de diversidade linguística e cultural com presença de ao menos quatro povos indígenas na condição designada pelo direito internacional como Povos Indígenas em Isolamento e Contato Recente (PIICR) (Vaz, 2019; Rivas Toledo, 2017; Trujillo, 2017, 2018; Salazar, 2017; Narváez, 2016; Vallejo \& Santamaría, 2016; Colleoni \& Proaño, 2010). Segundo dados oficiais proporcionados

\footnotetext{
2 A palavra wao siginifica 'gente', em oposição a cowode, que significa 'os canibais', ou 'a não gente'. "Es imposible comprender a los Huaorani del presente, sin referirse al Instituto Lingüístico de Verano (ILV), al cual se le debe que se les conozca con el nombre de Huaorani, esos seres humanos reales que hablan la lengua Huao" (Salazar, 2017, p. 1). Antes do ILV, os Waorani eram conhecidos como aucas, nome tomado da palavra quéchua que significa 'selvagem', 'infiel', 'primitivo' (Rival, 1994). Foram também conhecidos como Aushiris, Abijirias ou Zaparos (Rivas Toledo, 2017; Cabodevilla, 2016).

3 A experiência de redução da população em uma localidade geográfica específica transformou o nomadismo em um paulatino processo de vida sedentária, o que criou tensões interétnicas e elevou a mortalidade por epidemias nos grupos mais vulneráveis (Rivas Toledo, 2017, p. 50).
}

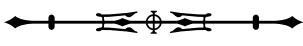


pelo Ministerio del Ambiente del Ecuador (MAE), foram identificadas ao menos quatro regiões com presença destes povos indígenas, que ocupam um território na fronteira ocidental e do sudoeste das províncias de Napo, Pastaza e Orellana, cercado pelo avanço da sociedade globalizada, nas formas de ameaças por parte de atores exógenos: campos e oleodutos petrolíferos, redes de transmissão de energia elétrica, estradas, missionários, colonos, agricultores, fazendeiros, caçadores, garimpeiros, militares, cientistas etc., o que converteu o território em uma 'jaula petroleira', com fronteiras artificiais e invisíveis, tanto políticas quanto econômicas (De Marchi \& Pappalardo, 2013; Rivas Toledo, 2017).

Do grupo antagonista sabemos muito pouco, apenas que são chamados Tagaeri-Taromenane e Iwene-Dugakairi. Para efeitos deste trabalho, interessam-nos os chamados Tagaeri-Taromenane, cujo idioma falado possivelmente pertence à família linguística wao-terero ${ }^{4}$, identificados como dois subgrupos de filiação Waorani (Trujillo, 2018; Rivas Toledo, 2017; Salazar, 2017). Estes grupos recusaram o contato no período do processo de pacificação, realocações e perda de território enfrentado pelos Waorani, devido ao avanço da fronteira de exploração do petróleo, das frentes missionárias e madeireira durante a década de 1960 (Colleoni \& Proaño, 2010, p. 6). Os Tagaeri têm sido identificados pelos Waorani como a 'gente Tagae', que se separaram dos Waorani há mais de cinquenta anos, habitam uma ampla região de floresta remota e, ao que parece, segundo testemunhos coletados pelo antropólogo Patrício Trujillo, foram absorvidos pelos Taromenane (Trujillo, 2017, p. 278; Salazar, 2017; Rivas Toledo, 2017). Este coletivo teria inusitado protagonismo nas décadas de 1970 e 1980 para evitar o contato através da guerra e da morte com lanças (Rivas Toledo, 2017, p. 50). Comandados por Tage ou Tagae, ocupou o território desde o rio Alto Tiputini até os rios Shiripuno, Tiguino e
Conanaco, mantendo relações tensas com outros grupos Waorani contactados, com os quais tiveram guerras de vingança abertas e cíclicas.

Os Taromenane ou 'gente do caminho's são chamados assim pelos Waorani e são considerados um grupo distinto, mas similar, no entanto, por aspectos na cultura e no idioma; se assume que os Taromenane são outros grupos Waorani não contatados, cuja separação ocorreu há várias gerações, possivelmente em finais do século $\mathrm{XIX}$ e durante todo o século $X X$, dentro dos ciclos de guerra e paz, próprios de sua vida social (Rival, 1994; Narváez, 2016; Álvarez, 2017; Rivas Toledo, 2017; Salazar, 2017). De acordo com Álvarez (2016, p. 73): "Al parecer, por estas presiones los Taromenane deciden por su seguridad física internarse en las cabeceras de los ríos Yasuní y Tiputini, y según Miguel Ángel Cabodevilla, se conoce que su líder fue Taromenga o Tarome", e que seu território ancestral é conhecido como Nemontare Guenwa, compreendido entre os rios Napo e Tigre, na fronteira entre Equador e Peru. Outros critérios etnográficos baseados em entrevistas de uma das irmãs de Tagae confirmariam que os Taromenane têm filiação linguística zapona, não utilizam orelhas furadas, além de informarem que a elaboração de lanças e zarabatanas é diferente. Assinala Izquierdo (1999, p. 74) que as casas construídas pelos Taromenane já encontradas seriam mais sólidas, em comparação com as casas tradicionais dos Waorani.

Estes grupos, com diversos traços culturais compartilhados com os Waorani e que optaram por estratégias de refúgio em pontos de difícil acesso da Amazônia equatoriana, são fruto de um extenso e prolongado processo de encontros e contatos desde o século $X I X$, que se intensificou durante finais do século $X X$ e começo do século XXI (Cabodevilla, 2016; Rival, 2004, 2015; Rivas Toledo, 2007). Somente o estabelecimento de

4 O idioma Huaorani/Waorani (wao tededo, tiriro ou terero) não tem afinidade com nenhuma outra língua ou grupo linguístico na Amazônia e é considerado isolado (Trujillo, 2018, p. 277).

5 Tarome significa 'caminho' em wao-terero (Rivas Toledo, 2017, p. 50).

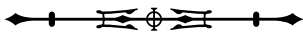


fronteiras políticas e econômicas em expansão (frontier) e a consequente situação de contato interétnico, pacificação, separação e dispersão dos coletivos Waorani tornam visíveis os Tagaeri-Taromenane em situação de isolamento voluntário como o 'outro' subalterno. Para os Waorani, estes grupos passam a ser parte de sua identidade multiétnica, sendo considerados uma espécie de 'parentes desconfiados' com os quais mantêm relações de aliança e intercâmbio, mas ao mesmo tempo que são inimigos 'selvagens' e 'mortais' com quem mantêm períodos de guerra.

Nesta relação, os Waorani teriam o monopólio do processo civilizatório e de integração nacional dos indígenas 'civilizados'. Há estudos etnográficos que mostram que, para a maior parte dos Waorani, os indígenas em isolamento voluntário são imaginados como pequenos grupos 'primitivos' e 'selvagens', que, apesar de protegerem seus territórios, "impidirían el desarrollo de la región" (Rivas Toledo, 2017, p. 55). Há aparições esporádicas e descontínuas dos Tagaeri-Taromenane, em geral, sempre breves e violentas, incluindo muitas aparições fora da Zona de Proteción Tagaeri-Taromenani (ZITT), situação que não permite formular uma visão precisa do território ocupado por eles. As áreas de maior ocupação se conhecem por medição de calor e ruído, segundo informou Manuel Bayon, do Coletivo Geografia Crítica (Pacheco, 2019).

Os fatos relacionados ao massacre de março de 2013 não podem ser analisados de maneira isolada, mas sim dentro de um contexto de ataques e contra-ataques realizados entre os Waorani e os Tagaeri-Taromenane ${ }^{7}$. As relações de contato do povo Tagaeri-Taromenane com seus vizinhos Waorani e com a sociedade envolvente local, nacional e global são historicamente intermitentes e relativamente esporádicas: quase sessenta anos de contato violento e desigual (Rivas Toledo, 2003; Narváez, 2018, p. 311). Os encontros têm sido tanto voluntários como involuntários, em sua maior parte violentos; expressaram-se tanto em compulsões externas, quanto em episódios de resistência, defesa, ataque e captura de objetos úteis (Rivas Toledo, 2017; Narváez, 2016; Álvarez, 2017, p. 45),

\begin{abstract}
sin relaciones sociales intensas hacia el exterior. Los pueblos son conocidos popularmente por su aparente 'violencia', noción basada en la mirada etnocéntrica de su cultura guerrera: son grupos humanos que practican las alianzas, pero también la muerte inter-tribal como una forma de establecer relaciones sociales intensas variablemente sostenibles a través del tiempo (Rivas Toledo, 2017, p. 68).
\end{abstract}

Fazendo-se uma revisão histórica dos registros de encontros violentos com os Tagaeri-Taromenane, temos a informação de que, no ano de 1971, ocorreu um primeiro enfrentamento com trabalhadores da companhia petroleira Western; logo após, em 1977, morreram, atingidos por lanças, três trabalhadores petroleiros; em 1987, morreram monseñor Labaka e Inés Arango, e no mesmo ano morreram mais quatro pessoas, registrando-se duas vítimas Tagaeri. Em 1993, faleceu Carlos Omene; em uma praia do rio Curaray, em 2001, dois anciãos kichwa foram atingidos por lanças; em 2002, morreram outros cinco madeireiros. Mariano Castellanos foi atingido por uma lança em 2007; em 2009, Sandra Zabala e seus dois filhos, Bayron e Damaris Duche, foram atingidos no setor da Precoperativa Unión. Os encontros violentos dos últimos vinte anos aumentaram drasticamente, com uma consequente aceleração súbita do número de vítimas

\footnotetext{
6 Categoria utilizada por Lucas Manxineru, líder indígena do povo Manchineri, em sua apresentação intitulada "Yine Manxinerune Hosha Hajane e a territorialidade criada na Terra Indígena Mamaodate: o poder das minorias", no Seminário Internacional "Povos indígenas em isolamento: repensando as abordagens antropológicas", ocorrido no Museu Nacional do Rio de Janeiro (Manchineri et al., 2018-2019).

7 As repercussões do massacre se manisfestaram com avistamentos e violência, que se tornaram patentes. Em janeiro de 2016, Caiga Baihua, um Waorani de 46 anos, foi atravessado por várias lanças e morreu na margem do rio Shiripuno, enquanto sua esposa, Oñenka Ñama, de 33 anos, conseguiu escapar na canoa a motor que os levava para sua comunidade, ainda que tenha levado uma lança cravada na perna e outra nas costas. O último contato registrado data de 12 de setembro de 2018, quando um grupo de 11 a 50 indígenas se acercaram da comunidade de Warentaro y Keweriono, buscando comida e deixando lanças em sinal de advertência.
}

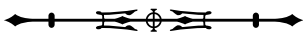


entre os povos em isolamento voluntário ${ }^{8}$, marcada por massacres perpetrados por membros do povo Waorani. Foram as guerras interétnicas ocorridas em maio de $2003^{9}$ e março de $2013^{10}$ que resultaram na morte de pelo menos cinquenta pessoas entre Tagaeri e Taromenane (Fundación Labaka, 2017, p. 2).

Estes dois últimos episódios de violência tiveram uma discreta cobertura da mídia nacional e internacional, no entanto provocaram ampla comoção na opinião pública e na comunidade acadêmica. $\bigcirc$ massacre de março de 2013, contudo, foi o único que teve a atenção dos tribunais de justiça do Equador, sendo que o fato foi judicializado como um caso de pluralismo jurídico, interculturalidade e conflito interétnico. Nestas circunstâncias, foi posto à prova o sistema de justiça ordinário e o sistema de proteção dos direitos humanos em nível nacional e internacional1". A Fiscalía General del Estado (FGE) anunciou que não permitiria a impunidade e abriu um expediente fiscal e um processo penal criminal contra os dezessete Waorani implicados. Na Audiencia de Formulación de Cargos, que ocorreu em 27 de novembro de 2013, o juiz de primeira instância decidiu abrir a instrução fiscal pelo presumido delito de genocídio, tendo sido ordenada a prisão preventiva dos Waorani suspeitos como medida cautelar. Não era difícil identificar os responsáveis, eles mesmos haviam se encarregado de oferecer declarações sobre seus atos, com o orgulho guerreiro que lhes caracteriza e que traz consigo prestígio social dentro de suas comunidades. Uns poucos suspeitos Waorani foram detidos, o restante buscou a clandestinidade (Salazar, 2017, p. 10).
O processo judicial avançou lentamente, enquanto alguns responsáveis aguardavam na prisão. $\bigcirc$ juiz de primeira instância negou três solicitações de medidas substitutivas e um habeas corpus. Em 16 de março de 2014, o juiz de primeira instância elevou o caso para consulta ante à Corte Constitucional do Equador, para que se resolvesse sobre a constitucionalidade da aplicação do tipo penal de genocídio, por ser contrário aos costumes e cosmovisões dos povos indígenas. A Corte Constitucional, em sentença, assinalou que, ao analisar se os membros do povo indígena Waorani cometeram genocídio, os elementos do tipo penal "deben ser considerados e interpretados desde una perspectiva intercultural [ênfase adicionada]" (Corte Constitucional del Ecuador, n.d.), e reconheceu que, apesar do tipo penal em si mesmo não apresentar vícios de constitucionalidade, "su aplicación al caso concreto generaría afectación a los derechos colectivos de los pueblos ancestrales que desconocen el contexto de la norma por ser ajena a su cosmovisión ancestral" (Salazar, 2017, p. 10). O juiz de primeira instância decidiu não criminalizar os indígenas por genocídio e absolver aos Waorani, atentando para o contexto intercultural no qual o fato em questão se realizou; a FGE apelou da decisão perante à Corte Provincial de Justicia de Orellana, a qual terminou por pronunciar-se a favor do julgamento perante o Tribunal Penal da Província de Orellana, processo judicial de julgamento cuja sentença foi emitida verbalmente em 31 de janeiro de 2019, na qual se responsabilizou por homicídio dez dos onze processados que compareceram à audiência de juízo.

8 A Comisión de Investigación do Ministerio de Justicia do Equador evidenciou que, nos últimos 30 anos, ocorreram 120 contatos entre os Tagaeri-Taromenane e os indígenas Waorani, dos quais 85 foram violentos (Plaza, 2018).

9 Ataque e assassinato de aproximadamente 20 pessoas taromenane, perpetrado por um grupo de indígenas waorani, motivados por madeireiros ilegais (Fundación Labaka et al., 2017).

10 Ataque e assassinato produzidos por uma espiral de vinganças, que culminou no massacre de ao menos 30 pessoas de um grupo tagaeri por parte de guerreiros waorani e que implicou também o sequestro de duas meninas.

11 Foram incrementadas as ações dos organismos internacionais de direitos humanos, como as medidas cautelares outorgadas pela $\mathrm{CIDH}$ (2013) e as Directrices de Protección para los Pueblos Indígenas en Aislamiento y en Contacto Inicial, elaboradas pelo Alto Comissariado de Direitos Humanos das Nações Unidas (2012), e foram implementadas ações de Estado, como a aplicação do Plano de Medidas Cautelares do MAE (2008), criando-se a Comisión para la Investigación de los Conflictos entre los Indígenas Taromenane y Waorani (2013), acompanhada de monitoramento e brigadas de saúde na ZITT.

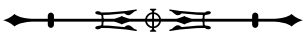


Com efeito, o Boletim de Imprensa Oficial FGE n. 22DC-2019 informou que, assim que a prova foi apresentada na audiência, a FGE demostrou: 1) a existência de uma organização por parte dos acusados, com o fim de buscar os rastros das famílias Tagaeri-Taromenane e perpetrar um ataque em represália à morte de dois anciãos de sua comunidade; 2) a existência do lugar onde se realizou o ataque; 3) o uso de armas de fogo e armas tradicionais no momento do ataque; e que 4) o ataque resultou na morte de indígenas em isolamento voluntário e, finalmente, no translado forçado de duas meninas. Em virtude destes fatos, o Tribunal, composto por três juízes, dispôs, em aplicação sem precedentes do princípio da interculturalidade, que a pena fosse imposta em coadunação com os anciãos Waorani, a fim de que esta estivesse de acordo com a cosmovisão dos membros deste povo. Com efeito, o Tribunal realizou uma reunião, em 7 de agosto de 2019, com anciãos Waorani (pikenanis) das comunidades envolvidas no conflito, com o propósito de que a imposição da pena fosse consequente com a cosmovisão Waorani, diligência que não foi compartilhada por todos os convocados.

Sem dúvida, é uma inovação na atividade judicial, sem precedentes na jurisprudência constitucional latinoamericana, que constitui um avanço importante de aplicação do chamado 'diálogo intercultural', como fórmula jurídica do pensamento decolonial, chamada a neutralizar a colonialidade do poder do Estado e que exige um grau de ativismo judicial e de interação dialógica com os povos indígenas. No entanto, esta decisão dos operadores jurídicos não esteve isenta de ambivalências. Finalmente, depois do que foi qualificado como conversatorio, seguindo as formalidades e os ritos performáticos do processo penal, e depois ". . . de haber recibido un condumio de ideas para la aplicación de un sanción con perspectiva intercultural", o Tribunal de Juízes declarou a culpa dos suspeitos, impôs uma sanção a dez dos dezessete acusados, modulou a sentença e substituiu a pena estabelecida por lei pelo trabalho comunitário de 200 horas ao ano durante quatro anos, dirigido ao semeio de roçados e à construção de casas tradicionais (onko) em comunidades próximas, além da organização e participação em uma festa intercultural, dando-se ênfase ao direito à 'vida'.

Para a execução do cumprimento destas sanções, os operadores jurídicos dispuseram que a Nacionalidad Waorani del Ecuador (NAWE), com seu autogoverno reconhecido pelo Estado, designasse uma comissão 'especializada' que facilitasse o canal de diálogo e coordenação com as comunidades Waorani, além de informar ao Tribunal as condições de cumprimento da pena a cada seis meses. Paradoxalmente, a coordenação significa uma cooperação ativa da justiça indígena como executora do poder punitivo simbólico e invisível do Estado, mas, ao mesmo tempo, a sentença é omissa em obter uma reparação integral das vítimas dos massacres, ou com a obrigação de determinar responsabilidades de agentes estatais e econômicos, atores sociais no território (envolvidos direta ou indiretamente por ação ou omissão no potencial genocídio das vítimas dos massacres).

Após um rápido e sumário processo de diálogo intercultural, os condenados e as comunidades em contato recente envolvidas foram chamados a ouvir, em 14 de agosto de 2019, a imposição da sentença no idioma espanhol e wao-terero, na comunidade de Pompeya, na província de Orellana, que os declarou responsáveis pelo crime de homicídio, registrada posteriormente por escrito ${ }^{12}$.

\section{A GUERRA, A VINGANÇA E A MORTE EM CONTEXTOS DE INTERCULTURALIDADE}

As dinâmicas de violência nos territórios têm padrões diferentes, no entanto, comparáveis. Tanto no massacre de maio de 2003 quanto no de março de 2013, há a organização de um grupo de guerreiros que buscam executar ações de

\footnotetext{
12 Sentença n. 2225120130223, de 31 de outubro de 2019, do Tribunal Penal da Província de Orellana do Equador, no processo judicial.
} Um recurso está atualmente pendente na Corte Provincial de Orellana. 
vingança (Narváez, 2016, 2018), ao mesmo tempo em que se intensifica a presença de agentes extrativistas.

O investigador pericial designado pelo Estado dentro do processo judicial teve acesso à evidência material: as lanças com as quais se executaram os ataques. Reconheceu traços decorativos e características físicas, como textura, confecção e decoração, que se alinham com eventos de violência anteriores. A etnografia requereu o levantamento de informação quanto às relações de parentesco mediante à reconstrução do grupo familiar dos executores do ataque. Foram registradas tanto as relações de parentesco ampliado com elementos de matrilocalidade, quanto as alianças baseadas em poliandria (Narváez, 2018, p. 315). As ações de vingança foram guiadas pelos parentes dos mortos mais velhos. Os Waorani que realizaram o ataque tinham como motivação praticar uma ação tradicional, enquadrada em seu ethos. De acordo com Narváez (2018, p. 318): "Para los Waorani, la venganza es una reacción social enmarcada en su cultura tradicional, en la que las alianzas se establecen a partir de relaciones de intercambio activas que son, para las sociedades, un contrato social".

Para Boaventura de Sousa Santos (2012), o reconhecimento do pluralismo jurídico implica o reconhecimento da ordem sociocultural indígena, fundada em uma cultura e um universo simbólico próprios, diferente da ordem sociocultural exercida pelo Estado nacional e pelo Direito Internacional dos Direitos Humanos (DIDH). Com efeito, o pluralismo jurídico põe em questão três princípios da arquitetura do Estado moderno: 1) a soberania e o monopólio das fontes jurídicas; 2) a unidade, a coerência e a completude do ordenamento jurídico do Estado; e 3) a autonomia do direito do Estado em relação a outros campos de regulação social mais legítimos em seus respectivos âmbitos. É provável que o pluralismo jurídico origine conflitos que coloquem problemas complexos de interpretação e interlegalidade ${ }^{13}$, como o descrito no estudo de caso. Desta maneira, as normas de legislação nacional, do direito internacional e da 'justiça' indígena, assim como os princípios diferentes da dignidade humana (e da própria concepção de pessoa) convergem, tensionando a universalidade abstrata dos direitos humanos (concepção ocidental) com as práticas e cosmovisões da 'justiça' indígena.

Aplicando uma hermenêutica de suspeita, deveríamos nos questionar: há algo nas práticas e epistemes indígenas que seja aproximado da noção ocidental de 'justiça'? A guerra tradicional interétnica pode ser considerada justiça indígena? A guerra tradicional interétnica pode ser compreendida como parte do direito coletivo de povos indígenas?

Dar resposta a estas perguntas complexas implica uma compreensão transcultural do ordenamento jurídico nacional, da ideia ocidental de 'direitos humanos' e das epistemes de cada povo. No início da década de 1990, começou a se delinear "um tipo de visão universalista dos direitos humanos mais sensível às críticas do relativismo cultural" (Baratto, 2009, p. 17), bem como do universalismo, qualificando ambas posições como "inaptas para responder aos desafios políticos que a implementação e o resguardo dos direitos humanos requer" (Baratto, 2009, p. 19). No mesmo sentido, Boaventura de Souza Santos opina que o debate sobre universalismo e relativismo cultural "se trata de um debate intrinsecamente falso, cujos conceitos polares são igualmente prejudiciais para uma concepção emancipatória dos direitos humanos" (Santos, 2009a, p. 18). Neste contexto, tomou-se a interculturalidade ${ }^{14} \mathrm{e}$

13 Relações sociais reguladas simultaneamente por mais de um sistema jurídico legítimo (Santos, 2012, p. 39).

14 Para Gunter Dietz (2017, p. 193), devido ao potencial crítico do conceito de interculturalidade, o termo também é utilizado de maneira prescritiva, como uma noção normativa, a interculturalidade em ocasiões chamada de "interculturalismo" (Gundara, 2000 citado em Dietz, 2017, p. 193), um programa transformador que tem como objetivo fazer com que as sociedades contemporâneas sejam mais conscientes de suas diversidades internas, e mais inclusivas e simétricas na relação com as suas - assim denominadas - minorias. Enfatiza a necessidade de transformar a natureza de relações entre estes grupos, o que implica não só o empoderamento de alguns, mas também alterar as percepções da maioria e promover os processos recíprocos de identificação entre grupos que foram privilegiados e aqueles que foram excluídos historicamente, "entre aqueles que não querem recordar e aqueles que não podem esquecer" (Santos, 2010, p. 131). 
o diálogo intercultural como perspectivas mais sensíveis a "evitar a chamada prepotência universalista e ao mesmo tempo a indiferença relativista" (Baratto, 2009, p. 19) para assegurar a legitimidade e a eficácia dos direitos humanos, buscando "a aceitação universal mediante a formação de um consenso sobre direitos humanos" (Baratto, 2009, p. 17), respeitando a diversidade cultural e a "existência concreta destes contextos culturais particulares dos sujeitos de direito" (Baratto, 2009, p. 17).

Para Gunther Dietz (2017, p. 194), na literatura produzida tanto no contexto europeu quanto no latinoamericano, percebe-se uma crescente tensão entre uma compreensão da interculturalidade como estratégia pragmática, político-educativa, para polir, suavizar ou mitigar as relações entre grupos - recurso funcional para elevar a tolerância e o entendimento mútuo -, e uma visão deste aspecto como estratégia transformadora para desvelar, questionar e transformar desigualdades historicamente arraigadas dentro da sociedade em termos de antidiscriminação e negociação de conflitos. Como estratégia transformadora, para Catherine Walsh (2009), a interculturalidade pode ser lida desde três perspectivas: a primeira é relacional - sua forma mais básica e geral, que remete ao contato e intercâmbio de culturas, onde é um instrumento de 'choque de civilizações', como concebido por Samuel Huntington (1993), com alcance universal obtido à custa de sua legitimidade local -; a segunda seria funcional - a qual se enraíza no conhecimento da diversidade e diferença cultural visando à inclusão no interior da organização social preestabelecida, calcada no Estado, buscando promover o diálogo, a convivência e a tolerância, sendo, portanto, funcional ao sistema existente, sem questionar o tema do poder (o reconhecimento da diversidade sendo uma modalidade da dominação); e uma terceira perspectiva, crítica, que não parte do problema da diversidade, e sim do problema estrutural-racial - isto é, entende-se a interculturalidade como uma ferramenta e como um processo construído desde a condição subalterna (Walsh, 2009, pp. 6-7).
Boaventura de Sousa Santos (2009b) estima que, em contextos de pluralismo jurídico como o descrito no caso em questão, a 'coordenação' e a 'convivialidade' são os princípios e os procedimentos que permitem um reconhecimento e enriquecimento, o que chamou de 'ecologia de saberes' (Santos, 2009b), ou seja, um intercâmbio de soluções jurídicas, em condições de interlegalidade e hibridismo jurídico. Cabe nos questionarmos: a interculturalidade pode se concretizar com povos em isolamento voluntário? Uma diligência judicial de 'conversatorio' pode tornar mutuamente inteligíveis os conflitos de guerra interétnica e os direitos humanos para os povos de recente contato Waorani e para os operados jurídicos? É possível uma relação de interculturalidade e diálogo em termos de igualdade, se não existe comunicação e coordenação com os povos em isolamento voluntário vítimas do massacre?

No entanto, interculturalidade não é uma questão técnica, mas uma questão política, que funde suas raízes na tensão regulação-emancipação (Santos, 2009b, p. 16). Os operadores jurídicos que judicializaram o caso do massacre dos Tagaeri-Taromenane fazem uso de elementos e informação etnográfica para o entendimento de um caso específico, e esta é sua contribuição para os padrões dos direitos humanos. No presente caso, pode-se identificar uma política judicial do estado de 'supervisibilidade' da interculturalidade e ativismo judicial dialógico, frente a uma política de 'invisibilidade' das vítimas e dos responsáveis vinculados às ações ou às omissões criminais de genocídio e etnocídio.

\section{DISCUSSÃO: RELATIVIZANDO A INTERCULTURALIDADE E O DIÁLOGO INTERCULTURAL}

Há outra questão central para a apreensão da noção de interculturalidade: a pluralidade de suas origens. Enquanto parte de um contexto de mediação, ela tem sido elaborada em diversos lugares, por diversos atores, em diversos contextos de contato. Podemos considerar 
esta noção, do ponto de vista epistêmico e de acordo com o uso que movimentos indígenas fazem dela, como a representação de uma lógica, não simplesmente um discurso, construída desde a particularidade da diferença. Acompanhando as ações e reflexões realizadas no âmbito da Confederación de Nacionalidades Indígenas de Ecuador, Catherine Walsh percebe a interculturalidade como um conceito "formulado y cargado de sentido principalmente por el movimiento indígena ecuatoriano, concepto al que este movimiento se refiere hacia 1990 como um "princípio ideológico'” (Walsh, 2007, p. 47). Para esta autora, este conceito contrasta com outros conceitos acadêmicos por ter vindo de fora da academia. Nesta perspectiva, presume-se que ele foi incorporado ao corpo epistêmico ocidental por via de uma relação 'intercultural' entre pesquisadores, intelectuais, acadêmicos e indígenas em diversos contextos. A interculturalidade "reflete um pensamento que não se baseia nos legados coloniais eurocêntricos", posto que "não se origina dos centros geopolíticos de produção do conhecimento acadêmico" (Walsh, 2007, p. 48), ou seja, não se reduz a qualificar um tipo de relação, mas sim uma 'práxis'. Assim, o principal problema é lograr ver e escutar como esta práxis se realiza, e discernir os seus principais elementos.

Esforços nas ciências sociais - principalmente a antropologia social ou cultural - lidavam com o significado da noção de interculturalidade (também alocado em outras palavras e expressões) para a explicação de fenômenos de relações entre diferentes sociedades. Também sociedades indígenas (povos autóctones não ocidentais subjugados pela expansão colonial europeia e neocolonial dos Estados ocidentais e ocidentalizados) e as sociedades ocidentais e ocidentalizadas ${ }^{15}$, desde os primeiros contatos, mantiveram relações interculturais. Mas Walsh chama atenção para o movimento indígena equatoriano no momento em que faz resistência às ameaças à sua integridade, falando sobre uma teoria elaborada por eles sobre o contato, tornando práxis a própria experiência acumulada no contato.

Isto também ocorreu em diversos outros contextos da América indígena, por exemplo, no caso dos povos indígenas do norte amazônico. Povos como os Yanomami, os Waiãpi, os Makuxi, os Desana, os Tikuna, entre muitos outros, também criaram as formas de "pacificar o branco", colocando-se como sujeitos, e não vítimas, no contato (Carneiro da Cunha, 2000, p. 7). Fenômeno amplo da América indígena, a interculturalidade, enquanto proposta elaborada no seio das epistemologias indígenas, pode ser melhor compreendida com recursos comparativos das trajetórias de diversos povos. As 'cosmologias do contato' ameríndias (Albert \& Ramos, 2000), bases de elaborações epistêmicas, são tão diversas quanto os povos ameríndios. São fruto de uma experiência acumulada que resultou em epistemologias, no âmbito das quais se elaboraram os elementos de discursos, práticas, produção e reprodução material, isto é, produção e reprodução do conhecimento.

Presumir, contudo, que o que causou a possibilidade de elaboração do conceito de interculturalidade no seio do movimento indígena equatoriano foram as relações interculturais deturpa a dimensão puramente conceitual de cultura. Consequentemente, torna-se 'dado' um 'fato' socialmente construído: a relação intercultural. Torna-se 'dado' um conceito criado e desenvolvido no seio da epistemologia do dominador não indígena: a cultura. Os conceitos indígenas do conceito de cultura não são os conceitos ocidentais do conceito de cultura. Constructos conceituais baseados em noção de cultura serviram e servem aos não indígenas ocidentais para explicar, compreender e descrever o contato. O mesmo pode ser dito em relação aos povos indígenas que 'se apropriam' destes constructos conceituais, das mais diversas formas. Os constructos conceituais baseados no conceito de cultura, 'diversidade cultural', 'relações interculturais', 'diálogo

\footnotetext{
15 Falamos em sociedade com intuito de enquadrar o diálogo intercultural para além do diálogo com o Estado, mas também com o que
} se pode designar como sociedade civil - diálogo que muitas vezes se deu e se dá à margem do Estado. 
intercultural' etc., operados pelos Estados das Américas, tornam-se muitas vezes uma arma etnocida. Os constructos conceituais baseados no conceito de cultura, manejados no seio dos movimentos indígenas, tornam-se uma arma de reivindicação de direitos. Vale ressaltar que o termo 'movimento indígena' pode designar fenômenos bastante diversos nas Américas indígenas - desde fenômenos mais centralizados em países predominantemente andinos, como o movimento descrito por Catherine Walsh, até as articulações rizomáticas/moleculares das terras baixas sul-americanas - no caso brasileiro, notadamente a proliferação de associações indígenas de pequeno porte, com poucas articulações mais centralizadas.

A reivindicação por um Estado plurinacional e intercultural feita por organizações indígenas sul-americanas, e em particular no Equador, opera justamente no plano de um diálogo intercultural, do jogo político de traduções e ressignificações conceituais, 'mal-entendidos produtivos' e produções de conceitos. Tendo em vista os conceitos basilares para as reivindicações dos povos indígenas no sentido de garantir sua sobrevivência - nação, cidadania, natureza, território, direitos humanos, direitos coletivos, saúde, educação, cultura etc. -, há um processo de criação semântica calcada no trânsito entre diferentes epistemologias. Traduções que traem a língua receptora, e não a língua matriz, discussões internas (entre lideranças indígenas e seus coletivos representados) que manejam estas palavras, em direções múltiplas. Aquelas frases intrigantes ditas no interior de uma casa coletiva, nas quais palavras em espanhol, português, inglês, francês despontam no meio de um discurso em língua indígena. Tradução e traição da língua receptora, e não da emissora (Viveiros de Castro, 2015b, p. 87). No caso em questão, o processo de diálogo intercultural proposto pelo Estado, expresso em uma diligencia judiciaria, foi finalizado com a leitura da sentença e punição, em língua wao-terero, em um ato simbólico, levado a cabo com presença dos juízes do Tribunal e de dez dos dezessete acusados do massacre, que foram adornados com seus distintivos culturais. Provavelmente, muitas das palavras ditas na diligência haviam sido previamente refletidas em língua indígena, nas discussões internas dos Waorani.

Seja em reuniões em aldeias Waorani ou em aldeias Yanomami - para nos restringirmos a povos ameríndios da América do Sul amazônica, de recente contato -, nas quais estas belas frases em que palavras do idioma dos ameaçadores despontam, algo está sendo elaborado. Significados estão sendo criados. Não são apenas 'torções' de significados, em que haveria um esforço por incorporar este corpo estranho (a palavra, o conceito) ao diálogo e à reflexão, uma importação manca e incompleta, posto que não há um 'domínio' da epistemologia subjacente ao significado dado pelos ameaçadores àquela palavra. $O$ corpo estranho não se torna estranho, nem é incompleto. No momento em que é trazida para o idioma indígena, aquela palavra não é nem ressignificada nem compreendida de forma incompleta: a palavra é enriquecida de significado, o que destaca "o papel das culturas não ocidentais para a redefinição dos conteúdos e políticas de direitos humanos, as quais são, essencialmente, ocidentais" (Baratto, 2009, p. 17).

Como conceito significante, a palavra continuará sendo operada por todos os envolvidos no diálogo intercultural: interlocutores indígenas e não indígenas continuarão utilizando-a. Mas esta palavra é emitida por ambas as partes em interlocução, transita entre diferentes cognições, é manejada como uma ferramenta ou uma arma na arena do diálogo e, assim, há uma performance de múltiplos mal-entendidos. Mas o 'mal'-entendido é uma forma de designar um 'semi'-entendido. E, assim, o preenchimento do 'todo', os significados de uma palavra cujo corpo de significados transcende o ponto de vista de cada um de seus manejadores, ocorre no resultado final do diálogo: significa dizer que ocorre como desdobramento, em conclusão ao processo. Por exemplo, o novo significado da palavra território ocorre com o reconhecimento do território indígena por parte dos não indígenas, seja na figura jurídica que for, a depender das nomenclaturas e definições dos diversos Estados da América do Sul, e assim por diante, com outras palavras enunciadas no diálogo intercultural. 
Como aponta Albert (1995), especificamente para o discurso reivindicativo de territorialidades locais, há uma elaboração contínua do discurso indígena, o qual se constrói em referência ao quadro jurídico e administrativo imposto pelo Estado, como no julgamento dos Waorani, no caso em estudo. Este fenômeno seria a 'resistência mimética'. Para visualizar de maneira panorâmica esta ideia de Albert (1995), propomos entrelaçar algumas reflexões feitas no interior das ciências sociais. Primeiramente, há que se ter em conta que, no discurso ameríndio voltado para o diálogo com a sociedade ocidental, é realizado o manejo de uma indianidade genérica (Albert, 1995, p. 3). Isto é, desde o diálogo com gestores de políticas de Estado até discursos enunciados em organizações internacionais, como a Organização das Nações Unidas (ONU), a ideia ocidental de 'índio', carregada de expectativas de tipos de conduta (os estereótipos legados do 'bom selvagem'), é necessariamente articulada com as propostas políticas trazidas ao diálogo. A indianidade genérica abarca o próprio estatuto político dos indígenas, que é traduzido em um estatuto jurídico dos povos indígenas tanto em legislações específicas dos Estados quanto em tratados internacionais. Esta articulação é realizada em um contexto que Dussel (2016, p. 52) definiu como sobredeterminado por todo o período colonial.

Esta situação colonial coloca aqueles e aquelas que formulam estes discursos interculturais no polo mais fraco da interação. São aqueles que não detêm o poder material das armas e dos corpos de repressão, nem dispõem de um poder simbólico dos Tribunais de Justiça, como o Estado. São aqueles que, caso realizem violência e esta violência seja realizada dentro, ou sua realização seja trazida para a arena de domínio do Estado, como no caso Waorani, serão classificados como pessoas que cometeram crime nos marcos legais e jurídicos deste Estado, neste caso, homicídio. O impasse é particularmente sensível aqui: a fundamentação de uma etnicidade genérica e jurídica incorpora o discurso do Estado (Albert, 1995, p. 3). E aqui, parafraseamos Viveiros de Castro (2015a): aquilo que cada coletivo indígena entende ser (e é) é diferente daquilo que o Estado em particular postula (juridicamente e praticamente) que eles sejam. São múltiplos os motivos que fazem o Waorani serem Waorani ou os Yanomami serem Yanomami: depende essencialmente do ponto de vista. Como vimos, há linguagens e idiomas diversos para variados pontos de vista. O povo indígena, enquanto "multiplicidade viva, em perpétuo devir, em perpétua divisão, recombinação, diferenciação" (Viveiros de Castro, 2011, p. 261), desnuda, desmascara, os mecanismos jurídicos criados no âmbito do Estado e em organismos internacionais de consulta ou diálogo: estes mecanismos são puras abstrações.

Roberto Cardoso de Oliveira apontava, no prefácio à segunda edição do livro "O índio e o mundo dos brancos", de 1970, que seu objetivo era estudar "o sistema de relações, a sujeição e dominância dos grupos envolvidos, sua interdependência e as instituições indígenas e nacionais", não era o objetivo "tratar os grupos e categorias sociais emergentes da situação de contato como um sistema de elementos determinados pela conjunção intercultural [ênfase adicionada]" (Cardoso de Oliveira, 1981 [1964], p. 1). O objetivo era se afastar das noções utilizadas nos estudos de aculturação. Olhando para este momento, e vendo tudo o que sucedeu nas décadas subsequentes no que concerne à ascensão de movimentos indígenas sul-americanos e da entrada dos indígenas na arena política do Estado, e a construção de um diálogo intercultural concomitante à estruturação destes diversos movimentos indígenas, vemos o quão pertinente é afastar a noção de 'interculturalidade' da noção de 'conjunção intercultural'. A Confederación de Nacionalidades Indígenas do Ecuador, a Nacionalidade Waorani do Ecuador (NAWE) e tantas associações indígenas no Brasil demonstram, assim como a Hutukara Associação Yanomami ou a Associação do Movimento dos Agentes Agroflorestais Indígenas do Acre, que a interculturalidade é uma proposta política, e nada tem que ver com uma mestiçagem cultural. Não que haja repúdio a esta mestiçagem. Pelo contrário, quando a interculturalidade é realizada como proposta metodológica para produção de conhecimento, há uma abertura para a formação 
de conhecimentos híbridos, para um entrelaçamento epistêmico. Porém, talvez a proposta seja mais produtiva em sua dimensão política de aproximar atores sociais de diferentes sociedades em esforços políticos conjuntos do que realmente na produção de conhecimentos calcados em um entrelaçamento epistemológico.

Davi Kopenawa, o líder, porta-voz examã yanomami, aponta dois elementos intrínsecos à formulação do discurso intercultural, quando conta sua própria trajetória (Kopenawa \& Albert, 2010). O primeiro é o caráter da utilização da língua do branco como uma língua franca, idioma através do qual ele e outras lideranças indígenas de diversos povos podem se comunicar. O manejo da língua dos brancos é uma necessidade política também no que se refere à articulação entre diferentes povos indígenas, os quais não falam a mesma língua. Este manejo, no início, é dificultoso justamente pelo pouco tempo de contato com a língua. Assim como acontece com qualquer pessoa que tenha que se comunicar em outro idioma, e o esteja aprendendo aos poucos. No estudo de caso, os pikenanis waorani expressam-se dentro do processo criminoso de homicídio, como consta da evidência documental processual, em espanhol.

Novamente, trata-se da questão basilar dos limites da interculturalidade. A guerra interétnica waorani tem seus fundamentos, seja como se queira defini-los: epistemológicos, cosmológicos... Fiquemos com a expressão genérica 'fundamentos culturais'. Assim, é possível propor que um guerreiro waorani não teria dificuldades de explicá-la dentro do seu contexto cultural, utilizando-se da linguagem apropriada e trabalhando com as expressões e palavras adequadas em sua língua. A tradução para o espanhol desta explicação é possível, como toda a tradução é possível. Porém, há incompatibilidades conceituais entre os pensamentos waorani e ocidental sobre o que é certo e errado, justo e injusto. Analisando a atividade jurídica (Estado) que propõe um diálogo intercultural, temos um desafio posto de antemão ao jurista: essas incompatibilidades, em um nível mais profundo, levam ao questionamento sobre a própria existência de noções 'equivalentes' entre os pensamentos de uns e outros - mas a presunção de uma universalidade de noções como justiça, guerra, ou mesmo de qualquer noção, é um pressuposto opressor do entendimento eurocêntrico do pensamento de outros povos. O desafio está posto. Levar adiante uma proposta tão revolucionária quanto é a interculturalidade implica isto: superar de forma criativa e conjunta impasses aparentemente insolúveis.

O caso em questão é emblemático deste desafio justamente porque os Waorani são um povo de recente contato e os guerreiros waorani envolvidos no processo estão em um momento de aprendizado e apropriação da língua do branco. Entre os juristas responsáveis pelo caso e os antropólogos que lhes deram assessoria, tampouco há ainda alguém que domine minimamente o idioma dos Waorani. Isto nos faz retornar ao contexto mais amplo na América indígena, o da apropriação por parte dos indígenas da língua do branco, que é concomitante ao aprendizado.

Davi Kopenawa conta de suas primeiras experiências de manejo da língua do branco em contextos políticos. Sua primeira fala em público fora de sua aldeia foi em uma reunião com outros indígenas de diversos povos como interlocutores (se não indígenas estavam ou não no recinto não é relevante, pois o discurso enunciado era direcionado a outros indígenas):

\begin{abstract}
A primeira vez que falei da floresta longe de minha casa foi durante uma assembleia na cidade de Manaus [realizada pela União das Nações Indígenas em julho de 1983, na sede do Conselho Indígena Missionário]. Mas não foi diante de brancos, e sim de outros índios! Era a época em que os garimpeiros estavam começando a invadir nossas terras, nos rios Apiaú e Uraricaá. Então, Ailton Krenak e Álvaro Tukano, lideranças da União das Nações Indígenas, me convidaram a falar (Kopenawa \& Albert, 2010, p. 385).
\end{abstract}

O segundo elemento apontado por Davi Kopenawa é a emoção como motivação para aprender a falar aos brancos, bem como a sua língua e suas categorias. Quanto mais urgente os resultados do diálogo, a empreitada de 
aprender esta língua torna-se mais e mais decidida. A raiva pelas iniquidades perpetradas pelos brancos ao povo Yanomami fez com que, no início de sua trajetória, ele alcançasse um estado de espírito que não seria apaziguado enquanto a assimilação da língua do branco não fosse feita, e a possibilidade de falar aos brancos fosse adquirida. A história de Davi Kopenawa e de diversas outras lideranças da América indígena mostra que existem muitos caminhos, sempre coletivos, para a elaboração do que se pode chamar de um 'discurso intercultural'.

A questão central neste trabalho é o que se alcança com a interculturalidade, e por que não se alcança mais. Existem diversos elementos que podem ser considerados como os causadores das suas limitações. A capacidade de violência do Estado e de não indígenas com interesses opostos aos povos indígenas em assuntos que impactam diretamente as suas vidas, como disputas territoriais por atividades extrativas de recursos naturais, podem ser vistas como a principal limitação. Sem sombra de dúvida, é a mais óbvia. Propor diálogo a quem aponta armas é um desafio político bastante complexo. Aqui, é importante ressaltar o ponto de vista de Cardoso de Oliveira sobre as "pré-condições de um diálogo intercultural" (Cardoso de Oliveira, 2000, p. 216):

O pressuposto sobre a viabilidade desse diálogo e, por conseguinte, a inteligibilidade do mesmo entre interlocutores, está na observância de um acordo intersubjetivo em torno de normas e de regras - explícitas ou implícitas, volto a dizer. Em suma, a observância de uma ética, aqui entendida como o dever de obediência às normas instituídas por consenso: a noção de etnicidade recobre precisamente isso. Entretanto, para que essas relações dialógicas ocorram num plano simétrico entre os interlocutores - indivíduos ou grupos - e mantenham um diálogo livre, sem a dominação de um interlocutor sobre outro, elas devem se dar num espaço substancialmente democrático ou, pelo menos, democratizável.

Além da questão da violência, podemos investigar outras limitações da interculturalidade (que podem ser trabalhadas e superadas), tanto em sua dimensão de proposta metodológica para a produção de conhecimento quanto em sua dimensão de estratégia política. Pensamos em uma chave ontológica. A ontologia ocidental e as ontologias ameríndias têm diferenças pressupostas, e o trânsito epistêmico entre elas é uma empreitada complexa (mas, de maneira nenhuma, impossível). Isto está relacionado à medida em que a concepção multicultural ocidental - que imagina múltiplas culturas e uma natureza externa e total à humanidade - diverge de forma quase que simetricamente oposta às concepções propostas por diversos povos ameríndios, nas quais

\begin{abstract}
. . . de um lado haveria uma unidade representativa puramente pronominal - é humano quem ocupa vicariamente a posição de sujeito cosmológico; todo ser existente pode ser pensado como pensante ("isto existe, logo isto pensa"), isto é, como um "ativado" ou "agenciado" por um ponto de vista -; do outro lado uma radical diversidade real ou objetiva (Viveiros de Castro, 2015b, p. 65).
\end{abstract}

Temos, assim, por um lado, o multiculturalismo como política de Estado e, por outro, a ontologia ameríndia como política cosmológica. Seja em um transe xamânico, ou em uma assembleia entre diversos povos indígenas, ocupando vagas em conselhos de órgãos públicos do Estado, ou em um processo de julgamento judiciário, haverá mais de uma linguagem, ainda que em um só idioma, posta na arena pública.

Fernando Garcés (2009, p. 21-23) chama atenção para o caso da Bolívia de que as chamadas políticas da diferença (multiculturalismo) na década de 1990, realizadas pelo Estado, vinham ao palco político como ferramenta de inclusão dos povos indígenas na modernidade neoliberal. Os mecanismos de reconhecimento e tolerância da diversidade não tinham outro propósito senão o de perpetuar a subjugação dos povos indígenas ao Estado, através de uma artimanha retórica de inclusão nas políticas de Estado. Trata-se da construção de uma cidadania indígena genérica, baseada em três pilares: a participação em políticas locais, a propriedade coletiva dos territórios tradicionais e a educação intercultural bilíngue. Neste momento da reflexão, tudo fica mais nítido com 
o apontamento de Enrique Dussel, quando se propõe a realizar um diálogo intercultural entre críticos das culturas ditas periféricas, de que, a partir da década de 1960, este diálogo intercultural perdera sua ingenuidade (Dussel, 2016, p. 52). A partir do final desta década, com o surgimento das ciências sociais críticas latino-americanas e seus frutos, como a teoria da dependência, o caráter opressor da arena em que ele é enunciado fica mais evidente: ele passou a ser compreendido, como apontado, como sobredeterminado por todo o período colonial. Dussel (2016) equipara diálogo intercultural com encontro de culturas, mas entende este encontro como um enfrentamento, de maneira nenhuma resultando em uma conjunção - este termo vago, que pode ter o sentido de uma mestiçagem cultural em uma acepção otimista ou, no pior dos casos, de um processo de etnocídio. A subjugação dos povos na situação colonial torna este diálogo assimétrico, realizado dentro de um contexto de dominação.

Ao termos contato com o pensamento de Fernando Garcés (2009, p. 21) sobre a interculturalidade, quando toma o caso boliviano como exemplo de confronto entre as políticas de diversidade cultural do Estado (multiculturalismo) e a interculturalidade enquanto teoria crítica da cultura elaborada pelos povos ameríndios, vemos ecos do que já havíamos discernido parcialmente, e que pode ser descrito como as duas vias pelas quais se realiza a proposta da interculturalidade como práxis indígena: interculturalidade como proposta metodológica para a produção de conhecimento e enquanto orientação para a produção de discursos na arena política do Estado.

\section{CONCLUSÃO}

A compreensão e a explicação de um caso relevante de guerra interétnica (no sentido apontado, de guerra entre etnias indígenas) podem revelar a emergência de contradições entre o ordenamento jurídico nacional e o ethos, tradições e costumes dos povos indígenas. As categorias de pluralismo jurídico e interculturalidade nos permitem compreender a ocorrência de uma diversidade de ordens sociais, políticas, jurídicas, culturais, étnicas, reconhecidas e igualmente válidas em um mesmo território. Evidentemente, o ordenamento jurídico nacional, em aparência hegemônico, precisa, dentro desta dita pluralidade, compreender as manifestações culturais da ordem social indígena, cujo reconhecimento também forma parte do marco jurídico constitucional.

No estudo de caso, que constitui um massacre perpetrado por uma etnia indígena a um coletivo de outra etnia, submetido à decisão de operadores jurídicos do Estado, nos encontramos frente a dois sistemas de pensamento diferentes: um que considera legítima e obrigatória a tipificação por homicídio, genocídio e etnocídio, e outro que tem a 'vingança' como base da guerra, que constitui um pilar de uma cosmologia ameríndia. Estamos diante de dois sistemas éticos. Deveríamos empregar o conceito rígido de relativismo cultural, considerando cada cultura em seus próprios termos? Mas, se fizermos isto, não seria possível ter um modelo universal de direitos humanos. Dilemas como o exposto requerem espaços de diálogo intercultural para a compreensão das particularidades culturais, com o fim de manejar as contradições em uma abordagem legal que articule os dois ordenamentos de condutas éticas. A implementação do diálogo intercultural para resolver as contradições produzidas pelo pluralismo jurídico é o objetivo de futuras investigações.

Embora estes desenvolvimentos jurisprudenciais deem algumas regras para o exercício da interpretação intercultural, o problema do pluralismo jurídico permanece sem solução. É possível que a ausência de aprofundamento se deva à esperança de que, em cada caso, o auxílio da perícia antropológica e sociológica resolva os conflitos; porém, se em realidade a interpretação jurídica aspira a ser intercultural, o juiz deverá ter capacidade de valorar e interpelar as informações periciais, para não ser substituído por aqueles em sua própria função de julgador (Pazos, 2018).

O caminho será sempre a abertura ao diálogo, colocando-o em uma perspectiva horizontal. Desta forma, 
soluções conjuntas poderão ser criadas, e poderão surgir noções novas, enriquecedoras para todo o contexto do contato. As limitações do diálogo intercultural no caso em questão estão expostas não apenas em suas dificuldades de comunicação horizontal, evidenciadas no processo judicial oficial, ao qual tivemos acesso, mas também através do caráter universal ou relativo de suas ordens sociais que operam na realidade social factual de contato e encontro. A ativação de mecanismos dialógicos requer aprofundar o diálogo além dos procedimentos judiciais para a construção de uma comunidade de comunicação. As limitações exigem estudos mais aprofundados dos efeitos das decisões judiciais e seu papel no estabelecimento de responsabilidades dos agentes do Estado e do mercado global envolvidos na complexa rede de relações que ocorrem no território Waorani-Tagaeri-Taromenani, bem como os efeitos dessas decisões nas comunidades ameríndias. Apesar das dificuldades, os desafios do diálogo intercultural são positivos para a garantia dos direitos humanos dos povos indígenas.

\section{AGRADECIMENTOS}

Esta pesquisa foi financiada pela Coordenação de Aperfeiçoamento de Pessoal de Nível Superior (CAPES) (processo 201914780003).

\section{REFERÊNCIAS}

Albert, B. (1995). O ouro canibal e a queda do céu: uma crítica xamânica da economia política da natureza. Série Antropologia, (174), 1-33. Recuperado de https://edisciplinas.usp.br/ pluginfile.php/1849409/course/section/474081/pub405-2.pdf

Albert, B., \& Ramos, A. (Orgs.). (2000). Pacificando o branco: cosmologias do contato no Norte-Amazônico. São Paulo: Editora UNESP, Imprensa Oficial do Estado

Álvarez, K. (2016). Lugares cargados de memoria: aproximaciones hipotéticas sobre la construcción de identidad y territorialidad en los Tagaeri y Taromenane. Antropología Cuadernos de Investigación, (16), 69-84. doi: https://doi.org/10.26807/ant. v0i16.25

Álvarez, K. (2017). Con ellos dentro: un siglo y más de continuo extermínio. In I. Vallejo \& R. Ávila Santamaría (Eds.), El último grito del Jaguar: memorias del I Congreso sobre Pueblos Indígenas Aislados en la Amazonía ecuatoriana. Quito: Abya-Yala.
Alvarsson, J.-A. (1999). Conflictos y guerras entre los weenhayek (mataco-noctenes). In: M. Califano (Ed.), Mito, guerra y venganza entre los Wichí (pp. 231-249). Buenos Aires: Ediciones Ciudad Argentina.

Alvarsson, J.-A. (2010). Shamanism and armed conflict - a case study of the interface between religion and war in aboriginal South America. Revista del CESLA, 1(13), 233-256.

Baratto, M. (2009). Direitos humanos e diálogo intercultural: possibilidades e limites (Dissertação de mestrado). Universidade Estadual de Campinas, Campinas, SP, Brasil.

Barrera, L. (2009). La circulación de expedientes y las formas de los expertos legales: agencia y sujeto en la Corte Suprema argentina. Revista Jurídica de la Universidad de Palermo, 10(1), 221-240.

Beriain, D. (2014). Yasuní. Genocidio en la Selva [Vídeo]. Documentário Discovery-Max. Recuperado de: https://www.dailymotion. com/video/x2yuh82

Bossert, F., \& Siffredi, A. (2011). Las relaciones interétnicas en el Pilcomayo medio: la guerra indígena y sus transformaciones (1882-1938). Población y Sociedad: Revista de Ciencias Sociales, 18(1), 3-48.

Cabodevilla, M. A. (2003). Reflexiones sobre un ataque Huao. Íconos - Revista de Ciencias Sociales, (17), 6-14. doi: https:// doi.org/10.17141/iconos.17.2003.460

Cabodevilla, M. A., \& Aguirre, M. (2014). Una tragedia ocultada. Quito: CICAME, Fundación Labaka, Gobierno de Navarra.

Cabodevilla, M. A. (2016). Los Huaorani en la historia de los pueblos del oriente. Quito: CICAME.

Califano, M. (1999). Mito, guerra y venganza entre los wichi. Buenos Aires: Ciudad Argentina Ediciones.

Cardoso de Oliveira, R. (1981 [1964]). O índio e o mundo dos brancos. Brasília: Editora UnB.

Cardoso de Oliveira, R. (2000). Ação indigenista, etnicidade e o diálogo interétnico. Estudos Avançados, 14(40), 213-230. doi: https://doi.org/10.1590/S0103-40142000000300018

Carneiro da Cunha, M. (2000) Apresentação. In B. Albert \& A. Ramos (Orgs.), Pacificando o branco: cosmologias do contato no Norte-Amazônico (pp. 7-8). São Paulo: Editora UNESP, Imprensa Oficial do Estado.

Carneiro da Cunha, M., \& Viveiros de Castro, E. (2017 [1985]). Vingança e temporalidade: os Tupinambás. In M. Carneiro da Cunha (Ed.), Cultura com aspas e outros ensaios (pp. 78-101). São Paulo: Ubu. 
Castro, M. (2014). Los puentes entre la antropología y el derecho. Orientaciones desde la antropología jurídica. Santiago: Universidad de Chile.

Cipoletti, M. S. (2002). El Testimonio de Joaquina Grefa, una Cautiva Quichua entre los Waorani (Ecuador, 1945). Journal de la Société des Americanistes, 88, 111-135. doi: https://doi. org/10.4000/jsa.2759

Clastres, P. (1987 [1981]). Investigaciones en Antropología política. México, DF: GEDISA.

Colajanni, A. (1984). Prácticas chamánicas y cambio social. La muerte de un hechicero Achuar: hechos e interpretaciones. In M. Brown (Ed.), Relaciones interétnicas y adaptación social, entre Shuar, Achuar, Aguarunas y Canelos Quichua (pp. 227-252). Quito: Abya-Yala.

Colleoni, P., \& Proaño, J. (2010). Caminantes de la selva. Los pueblos en aislamiento en la Amazonía ecuatoriana (Informe 7). Quito: IGWIA. Recuperado de https://www.iwgia.org/images/ publications//0275_Informe_7_eb.pdf

Comisión Interamericana de Derechos Humanos (CIDH). (2013). Informe de pueblos indígenas en aislamiento voluntario y contacto inicial en Las Américas. Doc 47/13. Washington, DC: CIDH, IWGIA. Recuperado de http://mww.oas.org/es/cidh/indigenas/ docs/pdf/informe-pueblos-indigenas-aislamiento-voluntario.pdf

Corte Constitucional del Ecuador. (n.d.). Sentencia No. 004-14-SCNCC. Recuperado de http://portal.corteconstitucional.gob. ec:8494/FichaRelatoria.aspx? numdocumento =004-14SCN-CC

Dasso, M. C. (2007). Apuntes sobre la justicia entre los wichi (Archivos, Vol. 5). Buenos Aires: CIAFIC Ediciones.

De Marchi, M., \& Pappalardo, S. 2013 (setembro, 27). iEn los próximo 30 años se puede excluir la presencia de los Tagaeri Taromenane en los Bloques 31 y ITT? Análisis crítico del informe preparado por el Ministerio de Justicia Derechos Humanos y Cultos el 21 de agosto de 2013. La Línea de Fuego. Recuperado de https:// lalineadefuego.info/2013/09/27/en-los-proximos-30-anos-sepuede-excluir-la-presencia-de-los-tagaeri-taromenane-en-losbloque-31-y-itt/

Descola, P. (1993). Lanzas del crepusculo. Relatos jibaros Alta Amazonía. México, DF: FCE.

Dietz, G. (2017). Interculturalidad una aproximación antropológica. Perfiles Educativos, 39(156), 192-207.

Dussel, E. (2016). Transmodernidade e interculturalidade: interpretação a partir da filosofia da libertação. Sociedade e Estado, 31(1), 5173. doi: http://dx.doi.org/10.1590/S0102-69922016000100004

Ecuador. (2008). Constitución de la República del Ecuador de 2008. Recuperado de http://www.oas.org/juridico/pdfs/mesicic4 ecu_const.pdf
Evans-Pritchard, E. E. (1977 [1940]). Los Nuer. Barcelona: Anagrama.

Fernandes, F. (2006 [1970]). A função social da guerra na sociedade tupinambá. São Paulo: Editora Globo.

Fundación Labaka, Acción Ecológica, \& Land is Life. (2017). Informe sobre pueblos indígenas aislados amenazados por la tala y la cacería ilegal en la Zona Intangible del Yasuní en el Ecuador. Quito: RIDH. Recuperado de https://tbinternet.ohchr.org/ Treaties/CERD/Shared\%20Documents/ECU/INT_CERD_ NGO_ECU_28081_S.pdf

Garcés, F. (2009). De la interculturalidad como armónica relación de diversos, a una interculturalidad politizada. In J. Viaña, L. Claros, J. Estermann, R. Fornet-Betancourt, . . . . \& E. Ticona (Orgs.), Interculturalidad crítica y descolonización: fundamentos para el debate (pp. 21-50). La Paz: III-CAB.

Gluckman, M. (2009 [1955]). Costumbre y conflicto en África. Lima: $\mathrm{UCH}$.

Gow, P. (2011). “Me deixa em paz!". Um relato etnográfico preliminar sobre o isolamento voluntário dos Mashco. Revista de Antropologia, 54(1), 11-46.

Gundara, J. (2000). Interculturalism, education, and inclusion. Londres: Paul Chapman Educational Publishing.

Huntington, S. P. (1993). The clash of civilizations. Foreing Affairs, 72(3). Recuperado de https://www.foreignaffairs.com/articles/ united-states/1993-06-01/clash-civilizations

Izquierdo, J. (1999). La ecoarquitectura: asentamientos humanos waorani. Quito: Abya Yala.

Juárez Ortiz, G. (2018). Como hacer etnografía en burocracias judiciales urbanas. Bravario para exotizar lo jurídico. In A. V. Estrada \& A. T. Salinas (Coords.), Etnografias: tacticas y estrategias para el registro y análisis de la diversidad cultural - apoyo didáctico para la investigación empírica (pp. 91-118). Querétaro, DF: Universidad Autónoma de Querétaro.

Kopenawa, D., \& Albert, B. (2010). A queda do céu: palavras de um xamã yanomami. São Paulo: Companhia das Letras.

Lévi-Strauss, C. (1976 [1942]). Guerra e comércio entre os índios da América do Sul. In E. Schaden (Ed.), Leituras de etnologia brasileira (pp. 325-39). São Paulo: Cia. Editora Nacional.

Manchineri, L. A. B., Virtanen, P. K., \& Ochoa, M. L. (2018-2019). Y Yine Manxinerune Hosha Hajene e a territorialidade na Terra Indígena Mamoadate, Brasil: o poder das memórias. Tipití, 16(1), 42-51. Recuperado de https://digitalcommons.trinity. edu/tipiti/vol16/iss1/5/

Metraux, A. (1950). A religião dos Tupinambás e suas relações com a das demais tribus Tupi-Guaranis (Brasiliana, Serie 5a, Vol. 267). São Paulo: Companhia Editora Nacional. 
Mixco, M. (1984). Paipai literature. The war of revenge. In L. Hinton (Ed.), Spirit mountain: an anthology of Yuman story and song (An American Indian Literary Series, Vol. 10, pp. 191-223). Tucson: University of Arizona Press.

Muzzopappa, E. (2010). Etnografía de un expediente judicial. La causa por espionaje en Trelew. In Anais das Sextas Jornadas sobre Etnografía y Métodos Cualitativos, Centro de Antropología Social, UBA, Buenos Aires. Recuperado de https://www.academia.edu/6566161/Etnograf\%C3\%ADa desde_un_expediente_judicial_La_causa_por_espionaje_ en_Trēew

Narváez, R. (2016). ¿Un ejercicio de aplicación de justicia intercultural? El caso Huaorani en la Amazonía ecuatoriana. Revista Antropologías del Sur, 3(6), 163-179.

Narváez, R. (2018). La etnografía, instrumento de investigación en antropología jurídica. El caso de un pueblo amazónico. Revista Temas Sociológicos, (23), 307-341. doi: https://doi. org/10.29344/07196458.23.1858

Pacheco, M. (2019, julho 26). La Producción de Petróleo de Ishpingo se difiere para el 2020. El Comercio. Recuperado: https://www.elcomercio.com/actualidad/ishpingo-licenciasambiente-petroamazonas-explotacion.html

Pazos, R. (2018). Interpretación intercultural de las decisiones judiciales. La fundamentación de la sentencia sobre la consulta de constitucionalidad de la norma en el caso penal WaoraniTagaeri-Taromenani. Recuperado de https://www.conpedi. org.br/wp-content/uploads/2017/08/Rina-Pazos-Equador.pdf

Pigliaru, A. (1959). La vendetta barbaricina come ordinamento giuridico. Milano: Ed. Giuffrè.

Plaza, J. (2018). Dos pueblos en aislamiento resisten el exterminio. La mula. Recuperado de https://ojoverdeecuador.lamula. pe/2018/04/04/dos-pueblos-en-aislamiento-se-resisten-alexterminio/jaimeplaza/

Price, D. (1983). La pacificación de los Nambiquara. América Indígena, 43(3), 601-628.

Resta, P. (2002). Pensare il sangue. La vendetta nella società albanese. Roma: Ed. Meltemi.

Rival, L. (1994). Los indigenas huaorani en la conciencia nacional: alteridad representada y significada. In L. Rival \& B. Muratorio (Eds.), Imágenes e imagineros (pp. 253-292). Quito: FLACSO.

Rival, L. (2004). El crecimiento de las familias y los árboles: la percepción del bosque de los Huaorani. In A. Surrallés \& P. G. Garcia (Eds.), Tierra adentro: territorio indigena y percepción del entorno (pp. 97-120). Lima: IWGIA.

Rival, L. (2015). Transformaciones Huaoranis: frontera, cultural y tensión. Quito: UASB.
Rivas Toledo, A. (2003). Sistema mundial y pueblos indígenas aislados en la Amazonía. A propósito del ataque a los Tagaeri. ÍCONOS: Revista de Ciencias Sociales, (17), 21-30. doi: https:// doi.org/10.17141/iconos.17.2003.477

Rivas Toledo, A. (2007). Los pueblos indígenas en aislamiento. Emergencia, vulnerabilidad y necesidad de protección. Revista Cultura y Representaciones Sociales, 1(2), 73-90.

Rivas Toledo, A. (2017). Los pueblos indígenas aislados del Yasuní, Amazonía del Ecuador. Una estrategia de protección integral y de educación ambiental (Tese de doutorado). Universidad Autónoma, Madrid, Espanha.

Romero, P. (2018). La persistencia de una cultura jurídica vindicatoria. El caso de los pastores de barbagia Cerdeña. Barcelona: Universitat de Barcelona Repositorio.

Salazar, D. (2017). Cuando la justicia no permite la paz: la necesidad de aplicar medidas de justicia transicional para proteger a los pueblos indígenas aislados en el Ecuador. (Relatório). New York: Yale University.

Santos, B. S. (2001). Para uma concepção multicultural dos direitos humanos. Contexto Internacional, 23(1), 7-34.

Santos, B. S. (2009a). Sociología jurídica crítica: para un nuevo sentido común en el derecho. Bogotá: Trotta.

Santos, B. S. (2009b). Más allá del pensamiento abismal. De las líneas globales a una ecología de saberes. In L. Olivé, B. S. Santos, C. S. Torre, L. H. Antezana, ...... H. J. Suárez (Eds.), Pluralismo epistemológico (pp. 31-84). La Paz: CLACSO, Muela del Diablo Editores, CIDES-UMSA-Comuna.

Santos, B. S. (2010). Refundación del Estado en América Latina. Perspectivas desde una epistemología del Sur. Lima: Instituto Internacional de Derecho y Sociedad, Programa Democracia y Transformación Global.

Santos, B. S. (2012). Justicia indígena, plurinacionalidad e interculturalidad en Bolivia. La Paz: Abya Yala.

Sassu, S. (2007). Ordinamenti giuridici di tradizione orale in Sardegna: il caso della "rasgioni" gallurese. Sociologia del Diritto, 28, 85-112.

Scionti, F. (2008). Pratiche di faida. Rappresentazioni della socialità in un contesto agro-pastorale contemporáneo. Foggia: Edizioni del Rosone.

Trujillo, P. (2017). Código Guerrero: movilidad, guerra y muerte con lanzas. Antropología Cuadernos de Investigación, 16, 85-98. doi: https://doi.org/10.26807/ant.v0i16.26

Trujillo, P. (2018). Identificación y dinámica de los pueblos indígenas en aislamiento voluntario (PIAV) en el Yasuní. Boletín de Antropología, 33(57), 271-276. 
Vallejo, I., \& R. Á. Santamaría (Eds.). 2016. El último grito del Jaguar: memorias del I Congreso sobre Pueblos Indígenas Aislados en la Amazonía ecuatoriana. Quito: Abya Yala.

Vaz, A. (2019). Pueblos Indígenas en aislamiento. Territorios y desarrollo en la Amazonía y el Gran Chaco. Informe Regional. Recuperado de https://andislife.org/wp-content/uploads/2019/10/Land-islife-25-septiembre-2019.pdf

Viveiros de Castro, E. (2011). A indianidade é um projeto de futuro, não uma memória do passado. Entrevista com Eduardo Viveiros de Castro. Prisma Jurídico, 10(2), 257-268.

Viveiros de Castro, E. (2015a). Sobre a noção de etnocídio, com especial atenção ao caso brasileiro. Recuperado de https://www.academia.edu/25782893/Sobre_a noC3\%A7\%C3\%A3o_de_etnocC3\%ADdi o_com -

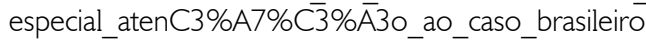

Viveiros de Castro, E. (2015b). Metafísicas canibais: elementos para uma antropologia pós-estrutual. São Paulo: Cosac Naify.
Viveiros de Castro, E. (2017). A inconstância da alma selvagem. São Paulo: Ubu.

Walsh, C. (2007). Interculturalidad y colonialidad del poder. Un pensamiento y posicionamiento "otro" desde la diferencia colonial. In S. Castro-Gomez \& R. Grosfoguel (Eds.), El giro decolonial: reflexiones para una diversidad epistémica más allá del capitalismo global (pp. 47-62). Bogotá: Siglo del Hombre Editores.

Walsh, C. (2009). Interculturalidad, estado, sociedad. Luchas (de)coloniales de nuestra época. Quito: Universidad Andina Simón Bolívar, Abya Yala.

Yost, J. (1981). Twenty years of contact: the mechanisms of change in Hua (Auca) culture. In N. E. Whitten (Ed.), Cultural transformations and ethnicity in modern Ecuador (pp. 677-704). Illinois: University of Illinois Press.

\section{CONTRIBUIÇÃO DOS AUTORES}

Os autores declararam participação ativa durante todas as etapas de elaboração do manuscrito.

\section{3}

\section{ERRATA}

Na página 1, onde se lia:

"The limits of intercultural dialog in contexts of interethnic warfare and legal pluralism: the case of the Waorani and Tagaeri-

Taromenane in Ecuador"

\section{Leia-se:}

"The limits of intercultural dialogue in contexts of interethnic warfare and legal pluralism: the case of the Waorani and Tagaeri-

Taromenane in Ecuador"

\section{Na página 1, onde se lia:}

"The goal is to describe the limits of intercultural dialog in a context of judicialization of traditional interethnic (...)"

\section{Leia-se:}

"The goal is to describe the limits of intercultural dialogue in a context of judicialization of traditional interethnic (...)"

Boletim do Museu Paraense Emílio Goeldi. Ciências Humanas, v. 16, n. 2, e2021-e001, 2021.

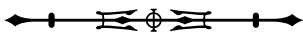


